\title{
Breast Cancer Pathologic Regional Lymph Nodes TNM Finding v8
}

National Cancer Institute

\section{Source}

National Cancer Institute. Breast Cancer Pathologic Regional Lymph Nodes TNM Finding v8. NCl Thesaurus. Code C139428.

A pathologic finding about one or more characteristics of breast cancer, following the rules of the TNM AJCC v8 classification system as they pertain to staging of regional lymph nodes. 